\title{
Mineral associations and their distribution in hydrothermal alteration zones of the Chelopech high-sulphidation deposit, Bulgaria
}

\section{Sylvina Georgieva}

Geological Institute, Bulgarian Academy of Sciences, Acad. G. Bonchev Str., Bl. 24, 1113 Sofia, Bulgaria; e-mail:sylvina@geology.bas.bg

(Accepted in revised form: October 2017)

\begin{abstract}
This study is focused on the mineral assemblages developed during hydrothermal alteration in the host rocks of the Chelopech deposit and aims to reveal some characteristics of ore-forming fluids. Three welldistinguished and simultaneously formed hydrothermal alteration zones, characterized by specific mineral associations, occur in the area: advanced argillic, sericitic and propylitic. The presence of silica residue localities in the advanced argillic zone marks the major channels of hydrothermal fluids and indicates participation of extremely acid fluids. The existence of alunite and zunyite in the alteration indicates development of acidsulphate hydrothermal environment, with presence of $F$ in the fluid, which is considered to be an important feature of ore-bearing high-sulphidation epithermal systems. Dickite in association with alunite in the upper levels of the deposit suggests temperature of formation $200-250{ }^{\circ} \mathrm{C}$. The highest temperature in depth is limited up to $375^{\circ} \mathrm{C}$, considering the occurrence of zunyite, pyrophyllite and dickite.
\end{abstract}

Georgieva, S. 2017. Mineral associations and their distribution in hydrothermal alteration zones of the Chelopech high-sulphidation deposit, Bulgaria. Geologica Balcanica 46 (2), 11-16.

Keywords: advanced argillic, sericitic, propylitic, acid-sulphate system, alunite, zunyite.

\section{INTRODUCTION}

The Chelopech high-sulphidation epithermal $\mathrm{Cu}-\mathrm{Au}$ deposit is located within the northern part of the Panagyurishte ore region, Central Srednogorie magmatic zone, Bulgaria. The genesis of the ore mineralization is related to Late Cretaceous magmatic activity. Since 1954, exploration and ore processing in the deposit have been extensively developed and have been the focus of extensive geological, mineralogical and hydrothermal alteration research. The deposit represents one of the most important $\mathrm{Cu}-\mathrm{Au}$ sources in Europe, with a past production of $19.8 \mathrm{Mt}$ ore with $1.2 \% \mathrm{Cu}$. According to Baltov and Donchev (2012), the processed ore in 2011 amounted to 357,036 t, with an average content of $1.37 \% \mathrm{Cu}, 3.89 \mathrm{~g} / \mathrm{t} \mathrm{Au}$ and $8.80 \mathrm{~g} / \mathrm{t} \mathrm{Ag}$. The hydrothermal alteration of the host rocks has been a subject of research since the first years of exploration (Chipchakova, 1966; Mutafchiev and Chipchakova, 1969; Radonova, 1969); however, there is some controversy about characteristics, type and stages of formation. This study aims to present a new perspective on mineral composition, zonal development and distribution of hydrothermal alteration in the area of the deposit.

\section{GEOLOGICAL SETTING}

The Chelopech deposit is a part of the Elatsite-Chelopech ore field and is hosted in Upper Cretaceous volcanic and volcano-sedimentary complex with transgressive position over high-grade metamorphic migmatized gneisses, schists and amphibolites and lowgrade metamorphic phyllites and schists. Lava flows, subvolcanic bodies, various breccias with volcanic elements and tuffs with andesitic, latitic, dacitic to trachydacitic composition are the main types of rocks hosting the ore mineralization (Stoykov et al., 2002). U-Pb zircon dating of andesites indicates an age of $91.45 \pm$ $0.15 \mathrm{Ma}$ (Moritz et al., 2003). The economic mineralization is concentrated among the volcanic breccias, commonly as stockwork, veins and disseminations. Massive or banded ore bodies with replacement tex- 
tures are related to volcanic tuffs. Large alteration halo with zonal character is developed in the rock complex, hosting the mineralization.

\section{METHODOLOGY}

Sampling covers the entire open and accessible area of the surface above the mine and in the underground galleries, mainly of level 405 (300-350 m below present-day surface). Material from the exploration drilling network, developed in the deposit, was also used. The mineral assemblages and the paragenetic relations of minerals were studied by transmitted and reflected light microscopy. The chemical composition of minerals was determined, using a scanning electron microscope (SEM) Jeol "Superprobe 733", with EDS HNU "System 5000" (Geological Institute, BAS) and electron probe micro-analyzer (EPMA) CAMECA CAMEBAX SX-50 (BRGM, Orleans, France). X-ray powder diffraction with a G-670 Guinier camera was carried out for defining the mineral composition of the rocks (Geological Institute, BAS).

\section{RESULTS}

The hydrothermal alteration of rocks is developed in large scale around the ore mineralization and is established in the whole investigated area, down to a depth of $2000 \mathrm{~m}$, covering subvolcanic bodies, phreatomagmatic breccia and associated tuffs and sedimentary rocks. The hydrothermal influx is favored by different fault systems and by the permeability of the host rocks. The most intensive alteration with silica residue occurs in the Central part of the Chelopech deposit, where the extraction of all components, except $\mathrm{SiO}_{2}$, leads to formation of vuggy silica or massive silica bodies.

Depending on the degree of alteration, there are three concomitant and well-distinguished zones observed in the host rocks: advanced argillic, sericitic and propylitic (Fig. 1). These zones are characterized

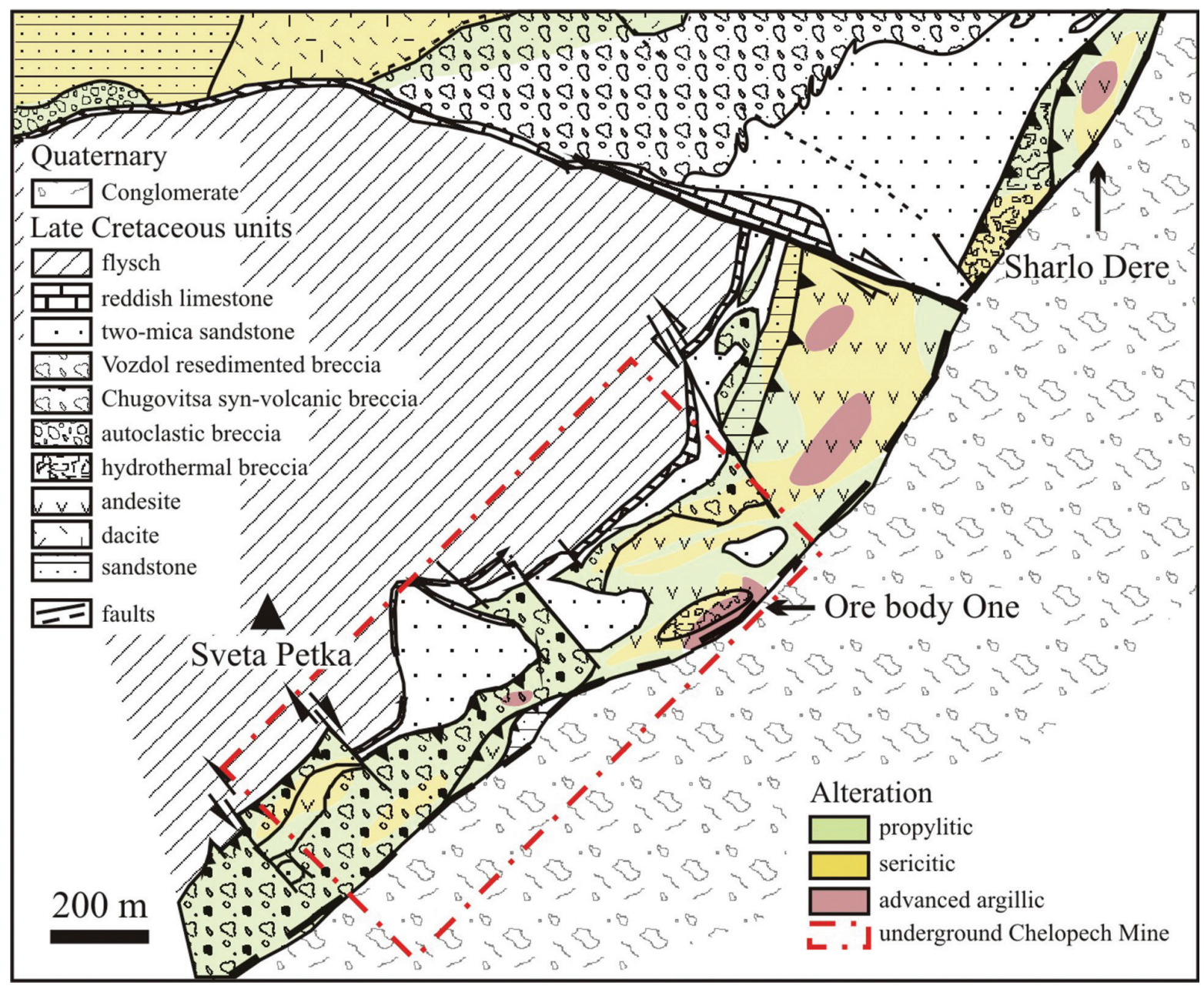

Fig. 1. Hydrothermal alteration on the surface area of the Chelopech deposit (after Radonova, 1969; modified with additions). Lithological basis after Chambefort (2005). 
by specific mineral associations with gradual transitions between them. The transition areas are marked by mixed mineral composition.

The advanced argillic zone traces the innermost parts of the hydrothermal system that is characterized by the deposition of the main ore mineralization volume and the presence of different hydrothermal breccia types (Fig. 2). The principal conductive hydrothermal flow channels are often indicated by the manifestation of silica residue localities. This alteration is developed in a close distance around the ore bodies and could be found mainly underground. On the recent surface, this zone is observed in limited locations. The best example is the area of Sharlo Dere, $\sim 1 \mathrm{~km}$ to the northeast from Chelopech mine, which is assumed to be an exhumed part of the deposit (Popov et al., 2000). The advanced argillic alteration is developed among different types of breccia, subvolcanic andesites, tuffs and sedimentary rocks and is reaches up to $2000 \mathrm{~m}$ in depth from the recent surface. Laterally, the spread of this zone is not large and usually develops within 100-150 m away from the ore bodies.
The mineral composition is quartz $(10-50 \%)$, dickite/ kaolinite (30-60\%), pyrite (10-30\%), alunite and aluminium phosphate-sulphate (APS) minerals $(2-10 \%)$, minor sericite (muscovite) and anatase. Pyrophyllite, diaspore and, rarely, zunyite have been documented in deeper levels ( $\sim 1000 \mathrm{~m}$ from recent surface) of the deposit. Quartz, dickite and kaolinite are the main alteration minerals in the advanced argillic zone, appearing in mixed aggregates of fine grains and flakes and completely replacing the primary mineral assemblage of the original rocks. The quantity of clay minerals generally predominates over the quartz among the tuffs and sedimentary rocks (dickite/kaolinite $>60 \%$ - quartz $<20 \%$ ), whereas among the breccias and subvolcanic varieties the ratio is quartz $>50 \%$ - dickite/ kaolinite $<30 \%$. Fine impregnation of pyrite is characteristic for all rock volumes. Thin veins and nests of the same mineral are also common.

In deeper levels of the deposit $(\sim 1000 \mathrm{~m}$ underground), the mineral assemblage in this zone is changed and various high-temperature minerals appear. Pyrophyllite occurs abundantly as $10-15 \mu \mathrm{m}$

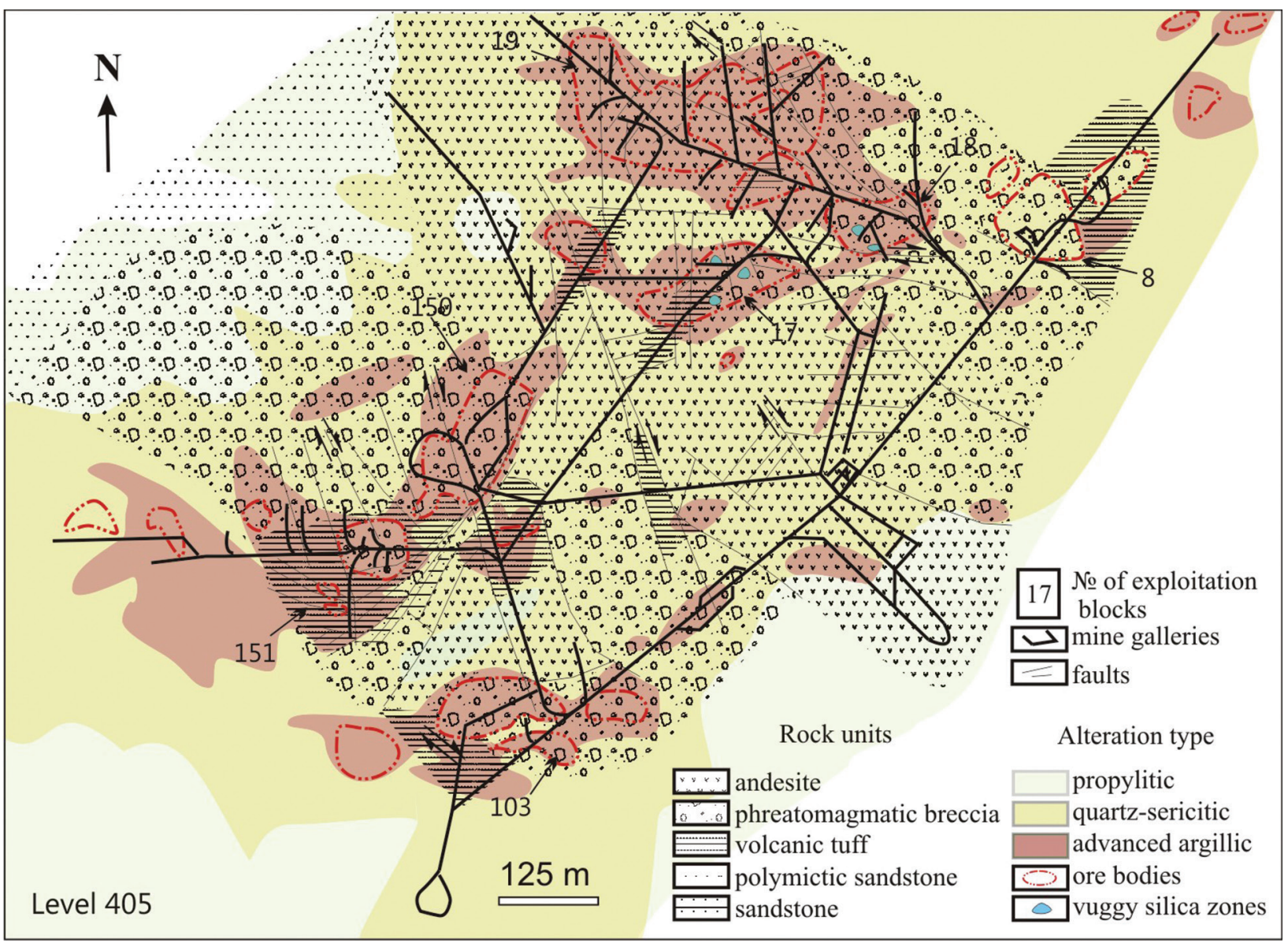

Fig. 2. Distribution of hydrothermal alteration and ore bodies in the Chelopech deposit according to unpublished data by Mutafchiev and Petrunov (1996; with additions) (underground operating mining level 405, 350 m under recent surface). Lithological basis after Chambefort (2005). Ore bodies are based on economic criteria. 
flakes in nests, thin veinlets or as alteration of clasts and phenocrysts along with dickite, quartz, pyrite and sometimes diaspore and zunyite. Its content in the rocks reaches up to $10 \%$. Diaspore is observed as fine irregularly shaped grains $(\sim 50 \mu \mathrm{m})$, disseminated in the whole rock in association with dickite, quartz, pyrite, pyrophyllite and rarely zunyite. Its content in the rocks is up to $5 \%$. Zunyite is not a common mineral in the deposit but is specific for the high-sulphidation epithermal system. Its occurrence has also been noted at depth more than $1000 \mathrm{~m}$ (Georgieva et al., 2002). Under the microscope, the mineral is colorless with parallel polarizers and isotropic with crossed polarizers and is observed as idiomorphic crystals with triangular sections with dimensions up to 200 $300 \mu \mathrm{m}$. This mineral, in association with pyrophyllite, diaspore and dickite, marks higher temperatures in the mineral-forming process.

Georgieva and Velinova (2012a) considered the presence of alunite in the deposit to be most abundant in the area of Sharlo Dere and sporadic, as single crystals, in the underground levels of the Chelopech mine. Recently, significant occurrence of this mineral was found in numerous drill cores from Western part of the deposit, in close association with the ore mineralization and variable content (1-20\% - Georgieva et al., 2016). Alunite occurs as pale to deep pink veins and nests and pseudomorphic replacements among the volcanic breccia, in association with dickite/kaolinite, quartz, APS, pyrite and enargite. The mineral forms tabular 5-600 $\mu \mathrm{m}$ crystals.

The presence of APS minerals in the advanced argillic zone of alteration is also common. They are observed as disseminated zonal crystals or irregular 5-150 $\mu \mathrm{m}$ grains, often enclosed in bladed alunite, or as micro-crystalline mass among clay matrix and quartz. The chemical composition of these APS generally represents svanbergite, svanbergite-woodhouseite solid solutions, woodhouseite, crandallite and florencite-(Ce, La, Nd) (Georgieva et al., 2002; Georgieva and Velinova, 2012b).

With a distance relative to the ore mineralization, the advanced argillitic alteration is gradually transformed to sericitic one, with development of a narrow intermediate zone with mixed mineral composition. This alteration covers wide area in the deposit and is usually traced up to 300-400 m away from the advanced argillic zone. Preserved primary textures of subvolcanic andesite, phreatomagmatic breccia, volcanic tuffs and associated sedimentary rocks can be recognized. The only relict minerals that may be observed are partially resorbed porphyry quartz and apatite in the volcanic rocks. Main minerals, developed during hydrothermal alteration, are fine-grained quartz, muscovite, illite, rarely kaolinite and rutile. Fine-grain pyrite impregnation is typical. The ratio of the major minerals in this zone is muscovite/illite $\sim 50 \%$ relative to quartz $\sim 30 \%$. The transition between sericitic to advanced argillic alteration is marked by increasing amount of kaolinite (up to 5\%) and occurrence of sporadic and very fine-crystalline APS mineralization $(10-50 \mu \mathrm{m}$ in size). The lack of apatite relicts in this intermediate area is also noted.

Propylitic alteration in the Chelopech deposit represents the outermost and remote area developed in the rocks of the volcanic complex. This alteration could be observed mainly on the surface, in the area above the mine, as well as in depth, apart from the sericitic zone established by drilling works. The rocks that have undergone this alteration usually have preserved original texture and partially preserved relics of magmatic plagioclase, quartz, amphibole and apatite phenocrysts. Main hydrothermal alteration minerals are quartz, albite, calcite, chlorite, pyrite, muscovite and rarely epidote. The transition towards sericitic zone is gradual and is most frequently marked by increased amount of muscovite.

Muscovite occurs in small quantities as finegrained aggregates or veinlets among the phenocrysts and matrix and often, along with chlorite and rarely epidote, replaces almost entirely the mafic minerals, such as amphibole and biotite. Albite is common mainly as metasomatic replacement in separate zones of primary magmatic plagioclase or as thin veins and nests, together with quartz and muscovite. The mineral generally forms limpid veinlets and aggregates up to $100 \mu \mathrm{m}$ in thickness. Calcite occurs as single clear euhedral, subhedral to anhedral crystals and grains or as nests and veins in the whole rock. Chlorite forms nests and impregnations, mostly in amphibole and biotite, but it also occurs in the matrix. The mineral is pleochroic of green to brown color and associates mainly with muscovite. Epidote is occasionally found in single fine grains in associations with chlorite and muscovite, as an alteration on mafic minerals. Quartz is observed in fine-grained nests and veins in the matrix or among plagioclase phenocrysts, in association with albite and muscovite. Pyrite impregnation is characteristic for all wall-rock alterations.

\section{DISCUSSION AND CONCLUSIONS}

Three main hydrothermal alteration zones are observed in the Chelopech deposit, formed as a result of a unified hydrothermal process and developed in a wide distance, laterally and in depth up to $2000 \mathrm{~m}$ in the volcanic complex. In the innermost part of the system, an advanced argillic zone is manifested, where the ore mineralization is embedded among different types of hydrothermal breccia. The presence of a silica residue area in this unit marks the major channels of the hydrothermal fluids. This zone, with a smooth transition and mixed mineral association, is transformed into sericitic alteration, which also gradually transforms to the most widely manifested propilitization. The main mineral association in the advanced argillic zone is composed of quartz, dickite, kaolinite, APS, alunite 
and pyrite. Pyrophyllite, diaspore, and zunyite occur in depth. Alunite forms at temperatures up to $500{ }^{\circ} \mathrm{C}$, high $\mathrm{SO}_{4}^{2-}$ activity, high oxygen potential and low $\mathrm{pH}$ values (0.8-5.3) (Hemley et al., 1969). APS minerals are stable up to $400{ }^{\circ} \mathrm{C}$, at high $\mathrm{PO}_{4}^{3-}$ activity, high oxygen potential and a wide range of $\mathrm{pH}(3-8)$, from acid to neutral (Ripp et al., 1998). The predominance of dickite in association with alunite and APS in the upper levels of the deposit suggests temperature of formation about $200-250{ }^{\circ} \mathrm{C}$ (Hemley et al., 1980), which is in accordance with the isotope temperature study $\left(213 \pm 7{ }^{\circ} \mathrm{C}\right)$ in pyrite-alunite pair sample from the deposit (Lerouge et al., 2006). In deeper levels of the deposit, where diaspore, pyrophyllite and zunyite appear in the mineral association, the temperature of formation increases. According to Hemley et al. (1980), the coexistence of pyrophyllite and diaspore indicates a temperature above $285^{\circ} \mathrm{C}$ and a very low $\mathrm{pH}(1-1.5)$. The experimental data of Zarayski et al. (1981) indicate a temperature interval of $290-410^{\circ} \mathrm{C}$ and $\mathrm{pH}<2-2.8$ as decisive factors in the formation of pyrophyllite-containing secondary quartzite. Similar interval of $270-390{ }^{\circ} \mathrm{C}$ as a necessary condition for the formation of quartz-pyrophyllite-muscovite paragenesis was defined by Ivanov (1984). The presence of zunyite, pyrophyllite and dickite in the mineral association limits the highest temperature of formation up to $375^{\circ} \mathrm{C}$ (Berman, 1988). In accordance with the obtained mineralogical and isotopic data, the temperature and conditions of formation in advanced argillic alteration of Chelopech deposit can be considered in the range of $200-250{ }^{\circ} \mathrm{C}, \mathrm{pH} 3-5$ in the upper levels and $>300{ }^{\circ} \mathrm{C}, \mathrm{pH}<3$ in deeper levels of the hydrothermal system. An exception of this assumption is the massive silicification ("vuggy silica" and "massive silica") areas at the high levels of the deposit, where the $\mathrm{pH}$ range is assumed to be extremely low. The presence of alunite and zunyite in the advanced argillic alteration indicates development of acid-sulphate hydrothermal environment with presence of $\mathrm{F}$ in the fluid, which is considered to be an important feature of ore-bearing high-sulphidation epithermal systems.

\section{REFERENCES}

Baltov, I., Donchev, I. 2012. Gold and auriferous ore georesources and processing technologies in Bulgaria. "Geology and mineral resources" Publishing house, Sofia, $298 \mathrm{pp}$.

Berman, R.G. 1988. Internally-consistent thermodynamic data for minerals in the system $\mathrm{Na}_{2} \mathrm{O}-\mathrm{K}_{2} \mathrm{O}-\mathrm{CaO}-\mathrm{MgO}-\mathrm{FeO}$ $\mathrm{Fe}_{2} \mathrm{O}_{3}-\mathrm{Al}_{2} \mathrm{O}_{3}-\mathrm{SiO}_{2}-\mathrm{TiO}_{2}-\mathrm{H}_{2} \mathrm{O}-\mathrm{CO}_{2}$. Journal of Petrology 29, 445-522.

Chambefort, I. 2005. The Cu-Au Chelopech Deposit, Panagyurishte District, Bulgaria: Volcanic Setting, Hydrothermal Evolution, and Tectonic Overprint of a Late Cretaceous High-sulphidation Epithermal Deposit. PhD thesis, University of Geneva, Terre et Environnement 52, 173 pp.

Chipchakova, S. 1966. Adularization of propylitized rocks of the Chelopech gold-copper-pyrite deposit, district of Pirdop. Review of the Bulgarian Geological Society 27 (3), 329-331 (in Bulgarian, with English abstract).

Georgieva, S., Velinova, N., Petrunov, R., Moritz, R., Chambefort, I. 2002. Aluminium phosphate-sulphate minerals in the Chelopech $\mathrm{Cu}-\mathrm{Au}$ deposit: Spatial development, chemistry and genetic significance. Geochemistry, Mineralogy and Petrology 39, 39-51.

Georgieva, S., Velinova, N. 2012a. Alunite from the advanced argillic alterations in the Chelopech high-sulphidation epithermal $\mathrm{Cu}-\mathrm{Au}$ deposit, Bulgaria: Chemistry, morphology and genetic significance. Geochemistry, Mineralogy and Petrology 49, 17-31.

Georgieva, S., Velinova, N. 2012b. Florencite-(Ce, La, Nd) from the advanced argillic alterations in the Chelopech high-sulphidation epithermal $\mathrm{Cu}-\mathrm{Au}$ deposit, Bulgaria. Bulgarian Geological Society, National Scientific Conference with International Participation "Geosciences 2012", Abstracts, 23-24.

Georgieva, S., Velinova, N., Trifonova, M. 2016. Characterization of alunite from deeper levels of the Western part of Chelopech high-sulphidation epithermal deposit, Bulgaria. Bulgarian Geological Society, National Scientific Confer- ence with International Participation "Geosciences 2016", Abstracts, 31-32.

Hemley, J., Hostetler, P., Gude, A., Mountjoy, W. 1969. Some stability relations of alunite. Economic Geology 64, 599612.

Hemley, J.J., Montoya, J.W., Marinenko, J.W., Luce, R.W. 1980. Equilibria in the system $\mathrm{Al}_{2} \mathrm{O}_{3}-\mathrm{SiO}_{2}-\mathrm{H}_{2} \mathrm{O}$ and some general implications for alteration/mineralization processes. Economic Geology 75, 210-228.

Ivanov I.P. 1984. Facial analysis of wall rock alterations. Nauka, Moscow, 172 pp. (in Russian).

Lerouge, C., Kunov, A., Flehoc, C., Georgieva, S., Hikov, A., Lescuyer, J.L., Petrunov, R., Velinova, N. 2006. Constraints of stable isotopes on the origin of alunite from advanced argillic alteration systems in Bulgaria. Journal of Geochemical Exploration 90, 166-182.

Moritz, R., Jacquat, S., Chambefort, I., Fontignie, D., Petrunov, R., Georgieva, S., von Quadt, A. 2003. Controls of ore formation at the high-sulphidation $\mathrm{Au}-\mathrm{Cu}$ Chelopech deposit, Bulgaria: evidence from infrared fluid inclusion microthermometry of enargite and isotope systematics of barite. In: Eliopoulos, D.G. (Ed.), Mineral Exploration and Sustainable Development. Millpress, Rotterdam, 1209-1212.

Mutafchiev, I., Chipchakova, S. 1969. Hydrothermal alterations of the rocks of the Senonian volcanic complex at the gold-copper-pyrite deposit of Chelopech near Pirdop. Bulletin of the Geological Institute, Series Metallic and Nonmetallic Deposits 18, 125-142 (in Bulgarian, with Russian and English abstracts).

Mutafchiev, I., Petrunov, R. 1996. Geological Genetic Models of Ore-deposit Formation in the Panagyurishte-Etropole Ore Region. Unpublished report for Chelopech LTD, 69 pp.

Popov, P., Petrunov, R., Kovachev, V., Strashimirov, S., Kanazirski, M. 2000. Elatsite-Chelopech ore field. In: Strashimirov, S., Popov, P. (Eds), Guide to excursions A and C. "Geology and Metallogeny of the Panagyurishte 
Ore Region (Srednogorie zone, Bulgaria). Geodinamics and ore deposits evolution of the Alpine-Balkan-Carpathian-Dinaride Province”. ABCD-GEODE 2000 Workshop, Borovets, Bulgaria, May 2000, 8-18.

Radonova, T. 1969. Secondary quartzites and propylites in the Chelopech copper-pyrite deposit (Bulgaria). Review of the Bulgarian Geological Society 30 (3), 251-267 (in Russian, with English abstract).

Ripp, G.S., Kanakin, S.V., Shcherbakova, M.N. 1998. Phosphate mineralisation in metamorphosed high-alumina rocks of Ichetuyskoye ore occurrence (south-west Transbaikali). Zapiski Vserossiyskogo Mineralogicheskogo Obshchestva 127 (6), 98-108 (in Russian).

Stoykov, S., Yanev, Y., Moritz, R., Katona, I. 2002. Geological structure and petrology of the Late Cretaceous Chelopech volcano, Srednogorie magmatic zone. Geochemistry, Mineralogy and Petrology 39, 27-38.

Zaraisky, G.P., Shapovalov, Yu.B., Belyaevskaya, O.N. 1981. Experimental studies of the acidic metasomatism. Nauka, Moscow, 218 pp. (in Russian). 